\title{
Reading the world through the educational curriculum: The Social Sciences curriculum in Brazil in the context of the rise of conservatism
}

\author{
Leyendo el mundo a través del currículum: El currículum de \\ Ciencias Sociales en Brasil en el contexto del auge del \\ conservadurismo
}

\author{
Amurabi Oliveira \\ Federaal University of Santa Catarina
}

\begin{abstract}
In Brazil, the growing political polarization that culminated in the election of Jair Bolsonaro in 2018 consolidated a shift in educational policy that had already been pointed out in previous years, as demonstrated by the Nonpartisan school movement performance. In this article, we analyze the curriculum of human and social sciences in secondary education in Brazil from the Brazilian Learning Standards, and how that document reflects the rise of these conservative movements. On the one hand, it was observed that important categories for the social sciences, such as gender, were removed, thus removing the centrality of categories such as racism and social inequalities; on the other hand, there is a strong dispute over the meanings of other concepts, such as human rights. Both actions converge to fine-tune the human and social sciences curriculum with the guidelines of conservative movements in the educational field.
\end{abstract}

Keywords: Teaching of social sciences; Brazil; Secondary education; Social science curriculum; Conservatism

\section{Resumen}

En Brasil, la creciente polarización política que culminó con la elección de Jair Bolsonaro en 2018 consolidó un giro en la política educativa que ya había sido señalado en años anteriores, como lo demuestra el desempeño del movimiento Escuela sin Partido. En este artículo, se analiza el currículum de las ciencias humanas y sociales en la educación secundaria en Brasil desde la Base Nacional Común Curricular, y cómo este documento refleja el surgimiento de estos movimientos conservadores. Se observó que, por un lado, han sido retiradas categorías importantes para las ciencias sociales, como el género, y también ha sido retirada la centralidad de categorías como el racismo y las desigualdades sociales; por otro lado, existe una fuerte disputa sobre los significados de otros conceptos, como los derechos humanos. Ambas acciones convergen en un intento de afinar el currículum de las ciencias humanas y sociales con los lineamientos de los movimientos conservadores en el campo educativo.

Palabras clave: Enseñanza de las ciencias sociales; Brasil; Educación secundaria; Currículum de ciencias sociales; Conservadurismo 


\section{INTRODUCTION $^{1}$}

The social sciences encompass a wide range of academic disciplines, focusing on analyzing social life in its broad sense. As Evans (2004) points out, this field is marked by numerous conceptual disputes, demonstrating the complexity of teaching social sciences at school. It is also necessary to recognize that the teaching of these sciences has been the subject of numerous disputes around a vision about the functioning of the society in which we live.

Despite these more general characteristics (to which are also added their link to training for citizenship and the consolidation of a democratic project; Pagès \& Santisteban, 2010) it must be recognized that the teaching of social sciences takes on unique characteristics in different national contexts, which reflects both the different organizations of the educational systems, as well as the different traditions of the social sciences in the school curriculum. There may be numerous combinations of academic disciplines in the school context. Each country's democratic trajectory also influences the configuration of these national traditions and the role that education and teaching of social sciences played in each of these countries.

When referring to the teaching of social sciences in Latin American countries, it is important to consider that numerous civil and military dictatorships marked the 20th century, in addition to coups d'état, often institutional coups. In this context, the social sciences have repeatedly assumed the role of disciplines responsible for disseminating the State's official ideology in anti-democratic contexts and representing relevant tools for the consolidation of re-democratization processes in these countries in other contexts.

Despite the advances observed in the last decades of the 20th century, when most Latin American countries that experienced civil-military dictatorships began their democratic transition, we have observed in recent years the rise of conservative populist governments, which appears to be a global phenomenon, considering the elections of Donald Trump in the United States, as well as Boris Johnson in the United Kingdom, Viktor Orbán in Hungary, Andrzej Duda in Poland, Recep Tayyip Erdoğan in Turkey, among others. In Latin America, the election of Jair Bolsonaro in 2018 in Brazil stands out, which has come to be called in/by the international press as a "Tropical Trump". As Estellés and Castellví (2020) indicate, the implications of the rise of authoritarian populism in the world have not been

\footnotetext{
${ }^{1}$ This article is the result of research carried out at the Autonomous University of Barcelona, supervised by Professor Antoni Santisteban with funding from the CAPES PVE-Junior Program.
} 
sufficiently discussed in the educational literature, despite its implication in several fields.

We started from the Brazilian case to debate social sciences teaching in the rise of conservative movements. In a more specific way, we will analyze the teaching of human and social sciences ${ }^{2}$ in the Base Nacional Comum Curricular - BNCC (Brazilian Learning Standards) for secondary education, highlighting its absences and obstacles to developing critical citizen formation. This analysis will be carried out considering the rise of political conservatism in the Brazilian educational field, emphasizing the action of the Escola sem Partido - ESP (Nonpartisan School) movement and the election of Jair Bolsonaro in 2018.

\section{THE TEACHING OF SOCIAL SCIENCES AND THE PENDULUM OF DEMOCRACY IN BRAZIL}

With the creation of the Ministry of Education and Public Health in 1930, the formation of a national education system in Brazil began. The foundation of this ministry occurred during the government of Getúlio Vargas (1882-1954), in the transition from the República Velha (Old Republic) to the Nova República (New Republic). During this period, there was a strong dispute between Catholics and Liberals over national education guidelines, with the Associação Brasileira de Educação (Brazilian Education Association), founded in 1924, the main space for these disputes (Cury, 1988). With the publication of the Manifesto dos Pioneiros da Educação Nova (Manifesto of the Pioneers of New Education) in 1932, there was a clear rupture between these two groups; the manifesto signed by liberal intellectuals claimed that the State should organize a general education plan, in addition to defending a single, public, secular school, mandatory and free (Xavier, 2002). It is also important to highlight that in 1934 a new constitution was promulgated, which established the elaboration of national education guidelines as the exclusive prerogative of the federal government.

This is a period marked by intense educational reforms carried out in Brazilian states, with the gradual process of "scientization" of the school curriculum, through the introduction of modern subjects, such as Biology, Sociology, and Psychology, especially in teacher training courses (Oliveira, 2013). In this context, the social sciences became targets of a strong dispute over the worldviews to be

\footnotetext{
${ }^{2}$ In Brazil, the nomenclature of human sciences, or human and social sciences, is more frequent to refer to the school curriculum's subjects.
} 
disseminated at school, as evidenced by the research by Cigales (2019) when analyzing school textbooks produced by Catholic intellectuals between the 1920s and 1940.

As a result of Vargas' civil dictatorship, a period known as the Estado Novo (New State), between 1937 and 1946, the school became one of the main ideological propaganda spaces of the political regime (Henn \& Nunes, 2013). In 1937, a new federal constitution was also promulgated, releasing the State from drawing up national education plans. During this period, the Catholic Church gains greater prominence in the educational field, with several Catholic agents taking on important bureaucratic positions.

As Avritzer (2018) demonstrates, democracy in Brazil has a pendular movement, marked by periods of greater expansion and greater setback. The period between 1946 and 1964 is considered a moment of expansion of democracy in Brazil, which is also reflected in the educational field. An example of this was the creation in 1962 of the school discipline Organização Social e Politica do Brasil - OSPB (Social and Political Organization of Brazil), idealized by Anísio Teixeira (19001971), still under the government of João Goulart (1919-1976), the last civil president before the military coup of 1964 . The discipline was linked to the idea of a citizen formation within a democratic ideal.

As Martins (2014) points out, despite the reforms produced in the educational field during the military dictatorship period (1964-1985), many subjects were kept in the curriculum, as is OSPB. However, there was a profound ideological reorientation in teaching this discipline, starting to occupy an important place in legitimating the authoritarian regime (Martins, 2014). In 1969, the discipline Moral and Civic Education was included in the Brazilian school curriculum, whose objectives were linked to the country's cult, traditions, obedience to the law, and religious values.

With the end of the military dictatorship, the school started to be understood as an important space for consolidating a new democratic project, and teachers started to be recognized as important agents in this process (Weber, 1996). Only in 1996 was a new Lei de Diretrizes e Bases da Educação Nacional - LDBEN (Law of Guidelines and Bases for National Education) enacted, which gave a strong centrality to training for citizenship and the world of work. From this law, Brazilian education takes on its current configuration, formed by early childhood education, primary education, and secondary education. It is important to indicate that 
Brazil's primary education takes nine years, and secondary education three years, with no post-compulsory stage.

The post-re-democratization period was marked by an expansion of the role of social sciences in the Brazilian school curriculum, mainly during the government of the Workers' Party (2002-2016), with the inclusion of the teaching of AfroBrazilian history and cultures in 2003, indigenous history, and cultures in 2008, as well as sociology and philosophy in 2008. This movement occurred precisely when Brazilian democracy seemed to be in the process of consolidation (Schwarcz \& Starling, 2018). However, as Avritzer (2018) indicates, the period after the impeachment of President Dilma Rousseff marks the beginning of a new democratic inflection in Brazil, which deepens with the rise of Bolsonaro in 2018. According to Burity (2020), this conservative wave in Brazil had been gaining visibility at least since the June 2013 demonstrations, which despite having started as a non-partisan movement, was gradually incorporated by conservative movements focusing on attacking the Workers' Party.

It would be inaccurate to say that the social sciences lost space in the school curriculum in less democratic periods; however, it is necessary to indicate that they were historically used as a space for the diffusion of a certain worldview. The strong link between citizen education and the social sciences directly impacted these sciences' orientation, as the concept of citizenship in democratic and authoritarian regimes in Brazil is altered.

\section{THE RISE OF CONSERVATISM IN CURRICULAR POLICIES IN BRAZIL}

The ESP movement emerged in 2004, founded by lawyer Miguel Nagib. Therefore, it emerged at a time when the Workers' Party already ruled Brazil; it can be considered the main organized movement in the educational field that has defended a conservative agenda in the educational field.

It is important to note that this movement gained greater visibility years later, within the political polarization process that Brazil has gone through, especially since 2013. Before that, however, it is important to mention that one of the main conflicts that the Workers' Party faced in the educational sphere it also occurred in 2011, when within the federal government's Brasil sem Homofobia (Brazil without Homophobia) program, it was proposed to include the teaching material Escola sem Homofobia (School without Homophobia), which became known as the "gay kit", as it was called by Jair Bolsonaro when he was a federal deputy. 
Later, during the 2018 election campaign, Jair Bolsonaro again referred to the "gay kit", indicating that the Ministry of Education would have distributed the book Aparelho Sexual e Cia (Sexual apparatus and company), translation of the French book Le Guide du zizi sexuel by Hélène Bruller, and that this book would be part of the "Children's LGBT Seminar" that was being promoted by the Workers' Party in the National Congress. It was later shown that both statements were false, integrating the set of fake news used during his election (Klem et al., 2020).

In the end, the government withdrew with the distribution of the teaching material School without Homophobia, which was a reflection of the strong performance of the evangelical group in the National Congress, as well as of the ESP movement, which started to gain more prominence in the national debate.

The ESP's performance was also decisive in other moments of delimitation of educational policies in Brazil, such as the National Education Plan's approval in 2014 , in which any mention of the word gender was removed. In 2017, a public civil action brought by this movement was judged, which aimed to annul a rule of the Exame Nacional do Ensino Médio - ENEM (National High School Exam), which penalized in the mark candidates who had violated human rights in their newsrooms; the action stated that it hurt freedom of expression, which was accepted by the Federal Supreme Court.

Referring to these setbacks in the Brazilian educational policy agenda in the recent period, emphasizing changes in the ENEM, Oliveira and Silveira (2020) state the following:

Therefore, the question that can be raised is the extent to which such actions mark not only a setback of human rights but also a displacement of the space for discussion and construction of an inclusive political agenda. We understand that the guarantee of maintaining the school as a space to foster the construction of a corporate project in which the culture of human rights is constitutive is a relevant element for the consolidation of democracy itself, and in this sense, the exclusion of the emphasis that this exam gives to this issue represents a setback that goes beyond the educational field. (p. 224, Author's translation).

In a more recent period, its strong performance in preparing the final version of the BNCC published in 2018 stands out, from which any mention of the word gender was also removed. There were intense disputes in the elaboration of the BNCC; it is relevant to highlight that it started to be elaborated still under the government of Dilma Rousseff. However, its final version was only published in 2018 under the government of Michel Temer. This context is marked by strong political instability, increased ideological polarization, numerous protests across Brazil against the president, and questioning his government's legitimacy since 
many consider that the impeachment in 2016 was a political coup (Souza, 2016). Therefore, it is not surprising that the educational policies produced in this period have also been questioned. As highlighted by Michetti (2020):

BNCC reaches the end of its creation and approval journey with its propelling agents, establishing it as a technical and democratic reality and, therefore, legitimate. At the same time, it reaches the threshold of its implementation process - which proves to be problematic for several reasons, including because it lacks legitimacy with implementers - with many agents in other positions in the social space declaring it illegitimate. On the one hand, there was not exactly indeterminacy in creating the BNCC, since the dominant positions managed to carry out their purpose and complete the document. However, the process was more complex than anticipated, and, even after being ratified, the Base faces opposition and criticism. (p. 14, Author's translation)

Michetti (2020) also indicates that the Evangelical Parliamentary Front has managed to remove the terms "gender" and "sexual orientation" from the BNCC. These issues are also articulated with the ESP movement. These changes occurred between the different versions of this document, which also resized school subjects' place in the national curriculum.

Silva and Alves Neto (2020) indicate that there were mild and deeper disruptions between the different versions of the BNCC, one of the most emphatic being changing the curriculum's organization by curriculum components competencies. According to the authors:

In Brazil, the way to group disciplines into regions has been to organize competences, but not necessarily in the social logic that originated this notion, as the 2014 document's authors tried. The social logic of the notion of competences as an active grammar of the 2018 BNCC document's pedagogical discourse is that of the field of production or the market as a regulator and selector of legitimate texts and codes. (p. 281, Author's translation).

In our analysis, this emptying of school subjects allows for a greater departure from historically central themes in the social sciences, such as social, racial, and gender inequalities. After removing concepts considered "ideological", the focus on competencies opens space for greater questioning about what teachers teach in the classroom, contesting the contents that are not strictly linked to these skills and competences. This issue proves to be especially complex in the context of posttruth, in which there is a strong questioning about the pedagogical work of teachers (Peters, 2017).

Despite these victories in the scope of educational policy, it is important to emphasize that the ESP movement has also suffered defeats, mainly in the judiciary's scope, since justice has blocked numerous bills of a law passed in the city 
councils and state legislative assemblies. In August 2020, the Federal Supreme Court considered the law passed in the State of Alagoas in 2016 to be unconstitutional. This legislation was inspired by ESP, which makes available on its website a model of a bill to be replicated in city councils and state legislative assemblies.

\section{THE TEACHING OF HUMAN AND SOCIAL SCIENCES ACCORDING TO BNCC}

As indicated, Brazil had not yet prepared a national curriculum proposal in the humanities and social sciences, although there have been attempts in this direction. The current LDBEN indicates that the basic education curriculum must cover social and political reality knowledge, especially in Brazil, but does not indicate disciplines or content to achieve this objective. After this law, some documents were produced in this direction, such as the Parâmetros Curriculares Nacionais PCN (National Curriculum Parameters), then the $\mathrm{PCN}+$, and, later, the Orientações Curriculares Nacionais do Ensino Médio - OCNEM (National Curriculum Guidelines for Secondary Education). These documents indicated a disciplinary organization of the secondary education curriculum, structured from Philosophy, Geography, History, and Sociology, even though they did not establish them as mandatory subjects.

It is also important to understand that these documents were produced at different times and within different managements of the Ministry of Education. On the one hand, between 1994 and 2002, Brazil was governed by Fernando Henrique Cardoso of the Brazilian Social Democratic Party; from 2003 onwards, Brazil was managed by Lula (2003-2010) and Dilma Rousseff (2011-2016) of the Workers' Party. These two administrations were marked by the production of these documents' and the Diretrizes Curriculares Nacionais para o Ensino Médio (DCNEM (National High School Curriculum Guidelines) of 1998 and the DCNEM of 2013. Moehlecke (2012) points out that the 1998 DCNEM was heavily criticized mainly for its excessive emphasis on flexibility, autonomy, and decentralization of the curriculum, subordinating education to the world of work's demands. Still, according to the author, despite the new DCNEM are inserted in a political, social, and educational context different from that experienced in the 1990s, some of the criticisms made at the time seem to remain relevant, the main advance being the possibility pointed to the construction of a national curriculum.

The movement to produce BNCC has, therefore, as a background, these different orientations in the documents guiding the curricula of Brazilian secondary education. Moreover, as previously indicated, the BNCC itself begins to be 
produced in one social and political context; however, it is finished in another. Despite indicating that the area of human and social sciences is formed by the disciplines of Philosophy, Geography, History, and Sociology, BNCC does not point to specific content for these disciplines, nor does it indicate their mandatory nature. The final version of the BNCC attributes to the Brazilian states the formulation of their curricula, although they must be in tune with this national document and textbooks, national exams, etc.

Although the BNCC does not indicate content to be taught, it points to fundamental concepts that must be present in the teaching of human and social sciences and the specific skills of this area. The fundamental categories would be: a) Time and Space; b) Territories and Borders; c) Individual, Nature, Society; d) Culture and Ethics; and, e) Politics and Labor. Whereas the specific skills of the human and social sciences would be:

1. Analyze political, economic, social, environmental, and cultural processes at local, regional, national, and world levels at different times, based on the plurality of epistemological, scientific, and technological procedures, in order to understand and critically position themselves to them, considering different points of view and making decisions based on arguments and sources of a scientific nature.

2. Analyze the formation of territories and borders in different times and spaces by understanding the power relations that determine the territorialities and the geopolitical role of nation-states.

3. Analyze and critically assess the relationships of different groups, peoples, and societies with nature (production, distribution, and consumption) and their economic and socio-environmental impacts, to propose alternatives that respect and promote awareness, socio-environmental ethics, and responsible consumption at local, regional, national and global levels.

4. Analyze the relations of production, capital, and labor in different territories, contexts, and cultures, discussing these relations' role in the construction, consolidation, and transformation of societies.

5. Identify and combat the various forms of injustice, prejudice, and violence; adopt ethical, democratic, inclusive, and solidary principles and respect human rights.

6. Participate in the public debate critically, respecting different positions and making choices aligned with the exercise of citizenship and their life project, with freedom, autonomy, critical awareness, and responsibility.

These competencies have specific skills to be developed in the students, although it is not pointed out which subjects or what content would be responsible for developing them. It is also important to highlight that in 2017, the reform of secondary education was approved in Brazil, enabling the existence of training paths by areas of knowledge in secondary education. Each State will decide what 
should be the common basis for its students and their specific knowledge of each training course. This arrangement must be carried out within three years of secondary education in Brazil and must follow the BNCC.

The BNCC also impacts other educational policies, such as the National Textbook Program and the National High School Exam. Therefore, even though BNCC does not specify what content should be taught, it has become one of the most important documents in Brazilian educational policy.

\section{THE IMPACT OF CONSERVATIVE MOVEMENTS ON BNCC: A CRITICAL REVIEW}

Regarding the general objectives of the humanities and social sciences, BNCC refers to diversity in race, religion, and ethnic traditions. Gender diversity is silenced, which reflects the strong role of moral agents in its elaboration. The emphasis on diversity, to the detriment of the debate on inequalities, also demonstrates a certain reading of social reality. Although the document does not abandon the idea of forming critical citizens, considering the deep social inequalities in Brazil (Scalon, 2004), the following question can be asked: how would it be possible to form critical citizens by exempting themselves from the debate about social inequalities?

As previously indicated, conservative movements have had a major impact on the development of educational policies in Brazil in recent years, which has accelerated in the post-impeachment scenario, and even more so after Jair Bolsonaro. On the ESP movement website, which gathers complaints against teachers accused of indoctrinating their students, there are mainly two main themes: the so-called "gender ideology" and the criticism of the capitalist system inequalities. Therefore, it is possible to infer that the critical drain that occurred in the BNCC affected the gender category and social inequalities. This does not mean that the word inequality is not found in the document; it is sometimes cited, mainly in the content referring to primary education. However, it loses centrality in secondary education. Moreover, the presentation of this concept is sometimes carried out ambiguously, as in the case below:

For example, capitalist society, while proposing the centrality of equal subjects, builds economic relations that produce and reproduce inequalities in the social body. (Ministério da Educação, 2018, p. 566, Author's translation)

The existence of inequalities in capitalism is recognized; however, it would also propose individuals' equality. Attention should also be paid to the fact that inequalities, when stated, are thought of either generically and abstractly, or very 
quickly as socioeconomic inequalities and ethnic-racial inequality. These questions, however, are not thought of in an intersectional manner, leaving open an understanding that there is no relationship between socioeconomic inequalities and ethnic-racial inequalities, even though there is a rich literature in the field of Brazilian social sciences that point to a strong relationship between these two social phenomena (Ribeiro, 2006; Hirata, 2014; Guimarães, 2016).

Equally striking is that racism gains little visibility within the BNCC, being present in the teaching of human and social sciences in secondary education only in one of the skills, indicating that the student must:

Identify, analyze and discuss the historical, geographical, political, economic, social, environmental, and cultural circumstances of conceptual matrices (ethnocentrism, racism, evolution, modernity, cooperativism/development, etc.), critically evaluating their historical significance and comparing them to narratives that contemplate other agents and speeches. (Ministério da Educação, 2018, p. 572, Author's translation)

Since racism is one of the structural characteristics of Brazilian society, relegating its debate to an element dissolved among others, composing a specific skill within a general competence seems to point to an understanding that racism is not a structuring element of social relations in Brazil. It should also be noted that the idea that Brazil had a "racial democracy," which was reflected in a deeply miscegenated population, persisted for a long time in the Brazilian social imagination, something that has been debated and questioned in the field of social sciences, as well as in struggles of the black movement (Guimarães, 2004). Seconding racism to understand the Brazilian social reality may be a consequence of reinforcing a harmonious vision of a society, which has also been placed on the political plane. Jair Bolsonaro has already spoken publicly on the subject, stating that racism in Brazil is something very rare, in addition to appointing journalist Sérgio Camargo to the position of president of the Fundação Palmares (Palmares Foundation), the institution responsible for promoting Afro-Brazilian culture, which has already stated that real racism only exists in the United States.

Therefore, the exclusion of themes relevant to the understanding of social reality is excluded from the BNCC, reflecting conservative agents' actions in its process. Macedo (2017) highlights the action of the School without Party movement, which separates what would be education, which would be linked to moral values and the family environment, from instruction, which would be knowledge and skills to be learned at school. For the author: 
This set of conservative demands from ESP to the "content" of the BNCC is very punctual and points less to what should be part of the curriculum than to what should be excluded to "serve everyone". The exclusions mentioned explicitly refer to a political party, racial, gender, and sexuality demands. The potential of these exclusions to displace the articulations on the BNCC is worrying, as they directly focus on the demands of minority groups - of race, gender, and sexuality - which, still timidly, have conquered some space. (p. 517, Author's translation)

Although human rights are frequently cited throughout the document, indicating mainly the need for students to understand their importance and seek to respect them, it is necessary to assess this issue in more depth. As well as the question of the secular State in the educational field, in which conservative agents no longer seem to dispute the end of the secular State, but rather the meaning that this concept takes (Oliveira, 2017); in the field of human rights, something similar has occurred.

The Jair Bolsonaro government created the Ministry of Women, Family, and Human Rights ${ }^{3}$; since its founding, this ministry has been under the command of Damares Alves, an evangelical pastor, which has produced numerous controversies in this field. For Maranhão and Franco (2019), the role of Minister Damares Alves puts education for human rights at risk, precisely because it presents a series of proposals in the educational field that denies gender identities, which seeks to stimulate homeschooling as a way of parents moving their children away from the "school influence", and she has proposed the creation of an official government channel for complaints against ideological indoctrination in schools, etc.

We want to demonstrate with this that BNCC ends up reflecting two distinct strategies of conservative movements in the field of education in Brazil: a) on the one hand, there is an emptying of relevant themes in the field of social sciences, which are not mentioned in the document, or which are dissolved amid other themes, with emphasis on the debate on gender and sexuality, social inequalities and racism; b) on the other hand, themes considered central, such as human rights, despite being incorporated into the official curriculum, become the subject of dispute in terms of the concept of delimitation by different groups, with an increasing role of conservative groups in these fields.

According to Estellés and Castellví (2020), educational policies may not be direct contributors to the ascent of extremist political movements, but they are

\footnotetext{
${ }^{3}$ The Human Rights Secretariat was created in 1997, becoming a ministry only in 2015, and has undergone some modifications since then. In addition to the incubations that belonged to the Ministry of Human Rights, the current ministry adds the indigenous policies that belonged to the Ministry of Justice.
} 
indirect contributors because they miss a unique opportunity to strengthen democratic institutions. We believe that this has occurred in Brazil, being reinforced by the strong participation of conservative movements in elaborating educational policies in the recent period.

\section{FINAL CONSIDERATIONS}

This article sought to critically analyze the teaching of human and social sciences in Brazil from the BNCC, historically contextualizing the teaching of such sciences. As indicated, although this curriculum proposal is beginning to be forged during the government of Dilma Rousseff, its completion only occurred in the postimpeachment context, which can be interpreted as a historical moment of retraction of the democratic project that had been solidifying in Brazil since the 1980s, after the military dictatorship.

The rise of conservative movements with a strong presence in educational policies, coupled with the election of Jair Bolsonaro, has directly impacted Brazilian education and the teaching of social sciences in particular (Oliveira, 2020). The withdrawal of the gender debate from the curricula and the less emphasis on discussions about social inequalities and racism points to solidifying a conservative agenda in the educational field.

As much as the scenario seems hopeless, it is important to highlight four elements:

1. BNCC has been strongly criticized by specialists in the area, as evidenced by the public position on the subject of several scientific associations .

2. As the formulation of the curriculum in a strict sense was left to the states, this means that the struggles were redirected to local and regional instances, opening space for other possible arrangements.

3. There has been an increasing number of spaces of resistance to these conservative movements in education, with emphasis on the Frente Nacional Escola sem Mordaça (National Front School without Gag).

4. These conservative movements have suffered numerous defeats in the judiciary's scope, which has reinforced the teaching autonomy.

Finally, it is important to state that although we start from the Brazilian case, the dynamics in that country reflect a more general movement in other countries. The rise of conservative movements and their action in educational policies is a global phenomenon, which has generated clashes and controversies at different levels, with a special impact on social sciences. Understanding the dynamics of this 
process is shown as a fundamental step for the analysis of the elaboration and implementation of educational policies in the contemporary world.

\section{LIST OF ACRONYMS}

- BNCC - Base Nacional Comum Curricular (Brazilian Learning Standards)

- DCNEM - Diretrizes Curriculares Nacionais para o Ensino Médio (National High School Curriculum Guidelines)

- ENEM - Exame Nacional do Ensino Médio (National High School Exam)

- ESP - Escola sem Partido (Nonpartisan School)

- LDBEN - Lei de Diretrizes e Bases da Educação Nacional (Law of Guidelines and Bases for National Education)

- OCNEM - Orientações Curriculares Nacionais do Ensino Médio (National Curriculum Guidelines for Secondary Education)

- OSPB - Organização Social e Política do Brasil (Social and Political Organization of Brazil)

- PCN - Parâmetros Curriculares Nacionais (National Curriculum Parameters)

\section{REFERENCES}

Avritzer, L. (2018). O pêndulo da democracia no Brasil: Uma análise da crise 2013-2018. Novos estudos CEBRAP, 37(2), 273-289. http://dx.doi.org/10.25091/s0101330020180002000

Ministério da Educação. (2018). Base Nacional Comum Curricular. Governo Federal do Brasil.

Burity, J. (2020). Conservative wave, religion and secular state in post-impeachment Brazil. International Journal of Latin American Religions, 4(1), 83-

107. https://doi.org/10.1007/s41603-020-00102-6

Cigales, M. P. (2019). A sociologia católica no Brasil: análise sobre os manuais escolares (19201940) [PhD thesis]. Federal University of Santa Catarina.

Cury, C. R. (1988). Ideologia e educação brasileira: católicos e liberais. Cortez.

Estellés, M., \& Castellví, J. (2020). The Educational implications of populism, emotions and digital hate speech: A dialogue with scholars from Canada, Chile, Spain, the UK, and the US. Sustainability, 12(15), 1-16. https://doi.org/10.3390/su12156034

Evans, R. W. (2004). The social studies wars: What should we teach the children? Teachers College Press.

Guimarães, A. S. A. (2004). Preconceito de cor e racismo no Brasil. Revista de Antropologia, 47(1), 9-43. https://doi.org/10.1590/S0034-77012004000100001

Guimarães, A. S. A. (2016). Formações nacionais de classe e raça. Tempo Social, 28(2), 161-182. https://doi.org/10.11606/0103-2070.ts.2016.109752

Klem, B. S., Pereira, M., \& Araújo, V. (2020). Do fake ao fato: (des) atualizando Bolsonaro. Editora Milfontes.

Henn, L. G., \& Nunes, P. P. C. (2013). A educação escolar durante o período do Estado Novo. Revista Latino-Americana de História, 2(6), 1040-1049. 
Hirata, H. (2014). Gênero, classe e raça Interseccionalidade e consubstancialidade das relações sociais. Tempo Social, 26(1), 61-73. https://doi.org/10.1590/S0103-20702014000100005

Macedo, E. (2017). As demandas conservadoras do movimento escola sem partido e a base nacional curricular comum. Educação \& Sociedade, 38(139), 507-524. https://doi.org/10.1590/es0101-73302017177445

Maranhão, E. M. A., \& Franco, Cl. (2019). "Menino veste azul e menina, rosa”: Educação domiciliar e as ideologias de gênero e gênesis de Damares Alves, a "ministra terrivelmente cristã" dos direitos humanos. Revista Brasileira de Histórias das Religiões, 12(35), $297-$ 337. https://doi.org/10.4025/rbhranpuh.v12i35.48106

Martins, M. C. (2014). Reflexos reformistas: o ensino das humanidades na ditadura militar brasileira e as formas duvidosas de esquecer. Educar em Revista, 51, 37-50. http://dx.doi.org/10.1590/S0104-40602014000100004

Michetti, M. (2020). Entre a legitimação e a crítica: as disputas acerca da Base Nacional Comum Curricular. Revista Brasileira de Ciências Sociais, 35(102), 1-19. https://doi.org/10.1590/3510221/2020

Moehlecke, S. (2012). O ensino médio e as novas diretrizes curriculares nacionais: entre recorrências e novas inquietações. Revista Brasileira de Educação, 17(49), 3958. http://dx.doi.org/10.1590/S1413-24782012000100003

Oliveira, A. (2013). O lugar da Antropologia na formação docente: um olhar a partir das Escolas Normais. Pro-Posições, 24(71), 27-40. http://dx.doi.org/10.1590/S0103$\underline{73072013000200003}$

Oliveira, A. (2017). "Estado laico não é Estado ateu": algumas reflexões sobre religião, Estado e educação a partir da "lei da bíblia" em Florianópolis/SC. Política \& Sociedade, 16(36), 449-473. https://doi.org/10.5007/2175-7984.2017v16n36p449

Oliveira, A. (2020). La enseñanza de las ciencias sociales en Brasil hoy. REIDICS: Revista de investigación en didáctica de las ciencias sociales, 7, 207-222. https://doi.org/10.17398/2531-0968.07.207

Oliveira, A., \& Silveira, T. G. (2020). O ENEM e os direitos humanos: entre os avanços e retrocessos de uma agenda. Estudos de Sociologia, 1(26), 209-233.

Pagès, J., \& Santisteban, A. (2010). La educación para la ciudadanía y la enseñanza de las ciencias sociales, la geografía y la historia. Íber. Didáctica de las Ciencias Sociales, Geografía e Historia, 64, 8-18.

Peters, M. A. (2017). Education in a post-truth world. Educational Philosophy and Theory, 49(6), 563-566. https://doi.org/10.1080/00131857.2016.1264114

Ribeiro, C. A. C. (2006). Classe, raça e mobilidade social no Brasil, Dados, 49(4), 833-873. https://doi.org/10.1590/S0011-52582006000400006

Scalon, M. C. (2004). Imagens da desigualdade. Editora UFMG.

Schwarcz, L. M., \& Starling, H. M. (2018). Brasil: uma biografia. Companhia das Letras.

Silva, I. F., \& Alves Neto, H. (2020). O processo de elaboração da Base Nacional Comum Curricular (BNCC) no Brasil e a sociologia (2014 a 2018). Revista Espaço do Currículo, 13(2), 262-284. https://doi.org/10.22478/ufpb.1983-1579.2020v13n2.51545

Souza, J. (2016). A radiografia do golpe. Leya.

Xavier, L. N. (2002). Para além do campo educacional: um estudo sobre o Manifesto dos pioneiros da educação nova (1932). Edusf.

Weber, S. (1996). O professorado e o papel da educação na sociedade. Papirus. 


\section{AMURABI OLIVEIRA}

$\mathrm{PhD}$ from the Federal University of Pernambuco (2011), professor in the Department of Sociology and Political Science at the Federal University of Santa Catarina, Brazil. CNPq researcher.

Oliveira, A. (2021). Reading the world through the educational curriculum: The Social Sciences curriculum in Brazil in the context of the rise of conservatism. Bellaterra Journal of Teaching \& Learning Language \& Literature, 14(2), e948. https://doi.org/10.5565/rev/jtl3.948

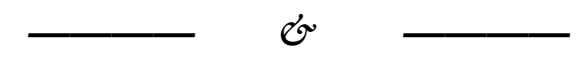

Rebut / Recibido / Received / Reçu: 04-09-2020

Acceptat / Aceptado / Accepted / Accepté: 11-06-2001 